\title{
EFFECT OF FENBENZYL AND FENBENDAZOLE ON THE ANTIOXIDANT STATUS IN DOGS DURING EXPERIMENTAL INFECTION WITH CAUSATIVE AGENT OF TOXOCARIASIS
}

V. V. STYBEL ${ }^{1}$, Doctor of Veterinary Sciences, Professor, Department of Parasitology and Ichtyopathology https://orcid.org/0000-0002-0285-6182

B. V. GUTYJ', Doctor of Veterinary Sciences, Professor, Department of

Pharmacology and Toxicology

https://orcid.org/0000-0002-5971-8776

W. S. SAID ${ }^{1}$, Graduate Student, Department of Pharmacology and Toxicology http://orcid.org/0000-0002-3273-4143

K. KUBIAK², Doctor Habilitatus, Professor, Department of Internal Medicine and Clinic of Diseases of Horses, Dogs and Cats

https://orcid.org/0000-0001-9640-2597

M. JANKOWSKI ${ }^{2}$, Doctor Habilitatus, Professor, Department of Internal

Medicine and Clinic of Diseases of Horses, Dogs and Cats

https://orcid.org/0000-0002-2356-2511

I. A. MAKSYMOVYCH ${ }^{1}$, Candidate of Veterinary Sciences, Associate Professor, Department of Internal Animal Diseases and Clinical Diagnostics

http://orcid.org/0000-0002-9012-0262

Z. A. GUTA ${ }^{1}$, Candidate of Veterinary Sciences

https://orcid.org/0000-0002-5652-6939

T. V. MARTYSHUK ${ }^{1}$, Candidate of Agricultural Sciences https://orcid.org/0000-0002-8445-1794

V. I. KARPOVSKYI ${ }^{3}$, Doctor of Veterinary Sciences, Professor, Department of Animal Biochemistry and Physiology named after Academician M. F. Gulyi https://orcid.org/0000-0003-3858-0111

${ }^{1}$ Stepan Gzhytskyi National University of Veterinary Medicine and Biotechnologies Lviv, 50 Pekarska st., Lviv 79010, Ukraine

${ }^{2}$ Wrocław University of Environmental and Life Sciences, 25 Norwida st.,

Wrocław 50-375, Poland

${ }^{3}$ National University of Life and Environmental Sciences of Ukraine, 15 Heroyiv Oborony st., Kyiv 03041, Ukraine

E-mail: bvh@ukr.net 
Abstract. The article presents the results of studies of the effect of fenbenzyl and fenbendazole on the antioxidant status in dogs under the experimental infection with a causative agent of toxocariasis. Experiments were performed on 18 dogs, two and four months old. Three groups of six animals in each were formed: control and two experimental. Puppies in all groups were experimentally infected with causative agent of toxocariasis at a dose of 5.000 embryonated Toxocara canis eggs per kg of body weight. The control group of dogs was as untreated control. Puppies of the first experimental group were fed with the drug fenbendazole at a dose of $150 \mathrm{mg}$ per $3 \mathrm{~kg}$ of body weight once a day for three days in a single dose. Puppies of the second experimental group were fed with the drug fenbenzyl at a dose of $350 \mathrm{mg}$ per $3 \mathrm{~kg}$ of body weight once a day for three days. While studying the activity of the enzymatic part of the antioxidant defense system, namely catalase, superoxide dismutase, glutathione peroxidase, glutathione reductase, as well as a non-enzymatic part: the level of reduced glutathione, an increase in the activity of these indicators was found in animals of experimental groups. It should be noted that the application of the drug fenbenzyl in infected dogs contributed to a better normalization of the antioxidant system in animals than the use of the drug fenbendazole. The use of fenbenzyl in infected dogs contributed to a more likely increase in the antioxidant status in dogs of the second experimental group, as this drug includes milk thistle that exhibits antioxidant properties due to the presence of silymarin, which restores damaged liver cells. Studies confirm the effectiveness of the use of milk thistle in drug fenbenzyl in dogs with the development of toxocariasis infection to activate the protective systems of their body.

Keywords: pollodoxin, doxycycline hyclate, broiler chickens, ornithobacteriosis, Ornithobacterium rhinotracheale, pharmacokinetic parameters

\section{Introduction}

The results of research and generalization of the literature indicate that among the parasitic diseases of dogs the most common in our country and abroad are gastrointestinal helminthiases, among which the leading place has toxocariasis nematode infection from the order Ascaridida (Pryima, 2010; Bodnia, 2016; Ozlati et al., 2016; Zibaei \& Sadjjadi, 2017).

It is known that the intestinal form of the disease is caused by mature Toxocara, and the larvae - visceral. In the process of migration, larvae, as well as their metabolites, can cause severe multiorgan damage up to death (Moisieieva et al., 2017; Said et al., 2018; Stybel et al., 2021). However, some mechanisms of activation of lipid-free radical oxidation processes in the development of toxocariasis in dogs and their relationship with the body's defense systems, especially the immune system, which is closely related to the antioxidant defense system in animals, remain unclear.

Toxocara plays a significant role in stimulating the formation of free radical oxidation and imbalance between oxidant and antioxidant content with the subsequent development in animals of so-called oxidative stress, including blood leukocytes, which are among the first to respond to changes in the environment under the influence of Toxocara metabolites (Robertson \& Thomson, 2002; Vidal et al., 2003; Svirzhevska, 2011; Macuhova et al., 2013). An important role in the 
development of oxidative stress in infected animals is the balance of prooxidant synthesis and antioxidant protection, the shift of this balance towards prooxidants causes compensatory activation of the antioxidant system from the damaging effects of free radicals and peroxide compounds (Martyshuk et al., 2016; Gutyj et al., 2017; Grymak et al., 2020).

The antioxidant defense system is a system responsible for regulating the intensity of radical formation and neutralization of peroxidation products (Martyshuk \& Hutyi, 2021; Varkholiak et al., 2021). The main mechanism of these reactions control is related to the chain of reversible redox reactions of metal ions, ascorbate, tocopherol, glutathione, and other substances (Martyshuk et al., 2021). In addition, the importance of these methods is especially important for the preservation of long-standing macromolecules of nucleic acids and proteins, some components of membranes (Holovakha et al., 2018).

As a result of the application of anthelmintic drugs for treating animals with toxocariasis, side effects caused by the reaction of dogs to the death of Toxocara can occur, because the destruction of Toxocara also leads to the release of toxins (Rubinsky-Elefant et al., 2011; Zakharchuk \& Harazdiuk, 2014; Noor et al., 2019; Said et al., 2020).

A wide range of anthelmintic drugs is used to treat dogs with toxocariasis. As a result of the destruction of parasites' bodies after the application of anthelmintics, somatic poisons and metabolites are released in the body of the host that cause intoxication and contribute to the reduction of its defense systems. The inclusion of milk thistle in the treatment of patients with toxocariasis allows to protect their body from the effects of parasite toxins and strengthen the immune and antioxidant potential.
Some authors have found a stimulating effect of milk thistle on the activity of antioxidant and hepatoprotective effects in animals (Toklu et al., 2008; Martyshuk \& Gutyj, 2019; Martyshuk et al., 2021). However, the complex application of milk thistle and fenbendazole on the function of the liver and the protective systems of the dog's body is currently insufficiently covered in the scientific literature.

That is why the purpose of the study was to investigate the effect of fenbenzyl and fenbendazole on the antioxidant status in dogs during experimental infection with the causative agent of toxocariasis.

\section{Materials and methods of researches}

The work was performed during 2017 2020 at the Department of Parasitology and Ichthyopathology, Stepan Gzhytskyi National University of Veterinary Medicine and Biotechnologies Lviv. The experiments were performed on 18 dogs, two to four months of age, and three groups of six animals were formed in each: control and two experimental groups. Puppies of all groups were experimentally infected with the causative agent of toxocariasis at a dose of 5.000 embryonated T. canis eggs per kg of body weight. The control group of dogs was as untreated control. Puppies of the first experimental group were fed with the drug fenbendazole drug at a dose of $150 \mathrm{mg}$ per $3 \mathrm{~kg}$ of body weight once a day for three days in a single dose. Puppies of the second experimental group were fed with the drug Ffenbenzyl drug (TC U 00492990-027:2020 "The drug Fenbenzyl") at a dose of $350 \mathrm{mg}$ per $3 \mathrm{~kg}$ of body weight once a day for three days.

The drug fFenbenzyl drug was developed at the Department of Pharmacology and Toxicology and the Department of Parasitology and Ich- 
thyopathology of the Stepan Gzhytskyi National University of Veterinary Medicine and Biotechnologies Lviv, which contains fenbendazole and milk thistle.

The state of the antioxidant defense system was assessed by the activity of catalase, superoxide dismutase, and indicators of the glutathione system in the blood. The activity of superoxide dismutase (SOD, EC 1.15.1.1) was determined by the method of Dubinina et al. (1983), catalase (CAT; EC 1.11.1.6) - by the method of Korolyuk (1988), glutathione peroxidase (GPx) (EC 1.11.1.9.) and glutathione reductase (GR) (EC 1.6.4.2.) - by the method of Lemeshko et al. (1985); the content of reduced glutathione (RG) - by the method of Butler (1963) (Vlizlo et al., 2012).

All animal manipulations were performed in accordance with the European Convention for the protection of vertebrate animals used for experimental and other scientific purposes (Strasbourg, 1986).

The analysis of research results was performed using the software package Statistica 6.0. The probability of differences was assessed by Student's t-test. The results of the mean values were considered statistically significant at $* \mathrm{P}<0.05,{ }^{*} * \mathrm{P}<$ $0.01, * * * \mathrm{P}<0.001$ (ANOVA).

\section{Results of the research and their discussion}

It is established that with the development of toxocariasis in dogs, the activity of the antioxidant defense system is suppressed, which is indicated by a decrease in the activity of its enzymatic and non-enzymatic parts. On the basis of the conducted researches it is established that during experimental toxocariasis in dogs on days 20 and 25 of the experiment, catalase activity in blood of animals of the control group decreased by $35.3 \%$ compared towith the initial values. The lowest catalase activity was in blood of infected dogs on day 30 of the experiment, where it was $0.09 \pm$ $0.06 \mathrm{mg} \mathrm{H}_{2} \mathrm{O}_{2}$, which was $47.1 \%$ lower than the initial values (Table 1).

It was found that catalase activity in animals of the first experimental group on the 5th day of the experiment increased to $0.17 \pm 0.03 \mathrm{mg}$ of $\mathrm{H}_{2} \mathrm{O}_{2}$ when fenbendazole was used in infected dogs. Subsequently, a decrease in the activity of this enzyme to $0.11 \pm 0.04 \mathrm{mg}$ of $\mathrm{H}_{2} \mathrm{O}_{2}$ was observed. It should be noted that on the 20th and 25th day of the experiment, catalase activity in blood of dogs of the first experimental group was higher by $27.3 \%$ compared with the control.

When using the drug Ffenbenzyl drug in infected dogs, an increase in catalase activity in their blood was found throughout the experiment. Thus, on the 15 th and 20th days of the experiment, an increase in the activity of this enzyme by 23.1 and $63.6 \%$, relatively, was found compared with dogs of the control group. On day 25 of the experiment, a slight decrease in catalase activity was observed in blood of dogs of the second experimental group compared with the previous day, but on day 30 of the experiment, again a high catalase activity was found in blood of dogs treated with fenbenzyl, where it increased almost 2 times compared with animals in the control group.

A decrease in superoxide dismutase activity in blood was also found with the development of toxocariasis in dogs, which at 20 and 25 days of the experiment decreased by 19.9 and $28.2 \%$ compared with the initial values taken before the infection with the causative agent of toxocariasis. On day 30 of the experiment, the activity of superoxide dismutase in blood of dogs of the control group was the lowest $-10.3 \pm 0.64$ $\mathrm{IU} / \mathrm{mg}$ protein (Table 2). 


\section{The effect of fenbenzyl and fenbendazole on catalase activity in blood of dogs infected with toxocariasis $(M \pm m, n=6)$}

\begin{tabular}{|l|c|c|c|}
\hline \multirow{2}{*}{ Blood test time } & \multicolumn{3}{|c|}{ Catalase activity, $\mathrm{mg} \mathrm{H}_{2} \mathrm{O}_{2}$} \\
\cline { 2 - 4 } & group of animals \\
\cline { 2 - 4 } & control & experimental 1 & experimental 2 \\
\hline Before treatment & $0.17 \pm 0.05$ & $0.15 \pm 0.04$ & $0.16 \pm 0.05$ \\
\hline Day 5 & $0.20 \pm 0.04$ & $0.17 \pm 0.03$ & $0.18 \pm 0.05$ \\
\hline Day 10 & $0.14 \pm 0.06$ & $0.15 \pm 0.03$ & $0.17 \pm 0.04$ \\
\hline Day 15 & $0,13 \pm 0.05$ & $0.15 \pm 0.04$ & $0.16 \pm 0.05^{*}$ \\
\hline Day 20 & $0.11 \pm 0.03$ & $0.14 \pm 0.06^{*}$ & $0.18 \pm 0.04^{* *}$ \\
\hline Day 25 & $0.11 \pm 0.05$ & $0.14 \pm 0.03^{*}$ & $0.16 \pm 0.02^{* * *}$ \\
\hline Day 30 & $0.09 \pm 0.06$ & $0.11 \pm 0.04^{*}$ & $0.18 \pm 0.05^{* * *}$ \\
\hline
\end{tabular}

Note: statistically significant differences were considered compared with the control group: $* \mathrm{P}<0.05 ; * * \mathrm{P}<0.01 ; * * * \mathrm{P}<0.001$.

The use of drugs fenbendazole and fFenbenzyl in dogs of the experimental groups contributed to the activation of superoxide dismutase activity in their blood, so on the 20th day of the experiment, the enzyme activity in dogs of the first experimental group increased by $17.6 \%$ and in the second experimental group - by $29.6 \%$ compared with the control. The highest superoxide dismutase activity was in blood of animals of the second experimental group on days 20 and 25 of the experiment, where it was $16.2 \pm 1.10$ and $16.0 \pm 1.56 \mathrm{UI} / \mathrm{mg}$ protein, respectively, which is $42.9 \%$ higher than the values in dogs of the control group. On the 30th day of the experiment, it was found that in blood of dogs of the second experimental group, the enzyme activity increased by $54.4 \%$, while in the first experimental group - by $37.9 \%$.

As a result of research, it is established that the development of toxocariasis in dogs of the control group causes

2. The effect of fenbenzyl and fenbendazole on superoxide dismutase activity in blood of dogs infected with the causative agent of toxocariasis $(M \pm m, n=6)$

\begin{tabular}{|l|c|c|c|}
\hline \multirow{2}{*}{ Blood test time } & \multicolumn{3}{|c|}{ Superoxide dismutase, IU/mg protein } \\
\cline { 2 - 4 } & control & experimental 1 & experimental 2 \\
\cline { 2 - 4 } & $15.6 \pm 0.70$ & $15.9 \pm 0.65$ & $15.7 \pm 0.68$ \\
\hline Before treatment & $17.1 \pm 0.95$ & $16.5 \pm 0.59$ & $16.9 \pm 0.87$ \\
\hline Day 5 & $15.2 \pm 0.54$ & $15.7 \pm 0.60$ & $16.0 \pm 0.94$ \\
\hline Day 10 & $14.4 \pm 0.82$ & $15.4 \pm 0.47$ & $15.9 \pm 0,99^{*}$ \\
\hline Day 15 & $12.5 \pm 0.86$ & $14.7 \pm 0.90^{*}$ & $16.2 \pm 1.10^{* *}$ \\
\hline Day 20 & $11.2 \pm 0.64$ & $14.4 \pm 1.05^{* *}$ & $16.0 \pm 1.56^{* * *}$ \\
\hline Day 25 & $10.3 \pm 0.64$ & $14.2 \pm 1.23^{* *}$ & $15.9 \pm 1.10^{* * *}$ \\
\hline Day 30 &
\end{tabular}

Note: statistically significant differences were considered compared with the control group: $* \mathrm{P}<0.05 ; * * \mathrm{P}<0.01 ; * * * \mathrm{P}<0.001$ 
a decrease in the level of reduced glutathione, one of the main indicators of the non-enzymatic part of the glutathione system of antioxidant protection. Thus, on the 15 th and 20th days of the experiment, the level of reduced glutathione decreased by 17.4 and $21.7 \%$ compared with the initial values. On days 25 and 30 of the experiment in blood of animals of the control group, the level of the studied indicator continued to decrease to $0.31 \pm 0.04 \mathrm{mmol} / \mathrm{L}$ (Table 3 ).

It should be noted that reduced glutathione is the main antioxidant for red blood cells, which plays the role of a coenzyme for methemoglobin reduction to functionally active hemoglobin. In addition, it involves the detoxification of several toxic compounds, as well as hydrogen peroxide and lipid hydroperoxides that are formed in the reactions of interaction of reactive oxygen species with unsaturated fatty acids of red blood cell membranes. Thus, reduced glutathione plays an important role in the maintaining functional characteristics of red blood cell membranes in dogs with the development of toxocariasis.

While studying the effect of fenbendazole and fenbenzyl on the level of reduced glutathione in blood of dogs infected with toxocariasis, it was found that its level in blood of the first experimental group on day 10 of the experiment was $0.43 \pm 0.04$, and the second experimental group $-0.45 \pm$ $0.05 \mathrm{mmol} / \mathrm{L}$, whereas in the control group this figure was significantly lower -0.40 $\pm 0.04 \mathrm{mmol} / \mathrm{L}$. On the 25 th and 30th day of the experiment, we note an increase in the level of reduced glutathione in dogs of experimental groups, so in the first experimental group this figure increased by 18.2 and $29.0 \%$, and in the second - by 42.4 and $45.2 \%$ compared with the control.

An equally important enzyme of the glutathione system of antioxidant protection is glutathione peroxidase, which catalyzes the reduction of hydrogen peroxide or organic hydroperoxides and consequently protects cells from the action of reactive oxygen species. The results of the studies showed that glutathione peroxidase activity decreased in blood of animals with the development of toxocariasis throughout the experiment. The lowest glutathione peroxidase activity was in blood of dogs of the control group on days 25 and 30 of the experiment, where it decreased by 23.9 and $26.7 \%$, respectively, compared with baseline values (Table 4).

\section{The effect of fenbenzyl and fenbendazole on the level of reduced glutathione} in blood of dogs infected with toxocariasis $(M \pm m, n=6)$

\begin{tabular}{|l|c|c|c|}
\hline \multirow{2}{*}{ Blood test time } & \multicolumn{3}{|c|}{ Reduced glutathione, mmol/L } \\
\cline { 2 - 4 } & \multicolumn{3}{|c|}{ group of animals } \\
\cline { 2 - 4 } & control & experimental 1 & experimental 2 \\
\hline Before treatment & $0.46 \pm 0.03$ & $0.44 \pm 0.04$ & $0.47 \pm 0.04$ \\
\hline Day 5 & $0.42 \pm 0.04$ & $0.45 \pm 0.05$ & $0.46 \pm 0.03$ \\
\hline Day 10 & $0.40 \pm 0.04$ & $0.43 \pm 0.04$ & $0.45 \pm 0.05$ \\
\hline Day 15 & $0.38 \pm 0.02$ & $0.41 \pm 0.03$ & $0.45 \pm 0.02^{*}$ \\
\hline Day 20 & $0.36 \pm 0.03$ & $0.40 \pm 0.05^{*}$ & $0.46 \pm 0.03^{* *}$ \\
\hline Day 25 & $0.33 \pm 0.05$ & $0.39 \pm 0.04^{*}$ & $0.47 \pm 0.02^{* *}$ \\
\hline Day 30 & $0.31 \pm 0.04$ & $0.40 \pm 0.06^{* *}$ & $0.45 \pm 0.03^{* * *}$ \\
\hline
\end{tabular}

Note: statistically significant differences were considered compared with the control group: * $\mathrm{P}<0.05 ; * * \mathrm{P}<0.01 ; * * * \mathrm{P}<0.001$. 


\section{The effect of fenbenzyl and fenbendazole on glutathione peroxidase activity in blood of dogs infected with the causative agent of toxocariasis $(M \pm m, n=6)$}

\begin{tabular}{|l|c|c|c|}
\hline \multirow{2}{*}{ Blood test time } & \multicolumn{3}{|c|}{ Glutathione peroxidase, $\mu$ mol $\mathrm{NADPH}_{2} \mathrm{~h} / \mathrm{mg}$ protein } \\
\cline { 2 - 4 } & \multicolumn{3}{|c|}{ group of animals } \\
\cline { 2 - 4 } & control & experimental 1 & experimental 2 \\
\hline Before treatment & $17.6 \pm 2.47$ & $17.8 \pm 3.10$ & $18.0 \pm 2.85$ \\
\hline Day 5 & $17.9 \pm 2.99$ & $18.0 \pm 3.15$ & $18.1 \pm 2.89$ \\
\hline Day 10 & $16.9 \pm 2.85$ & $17.5 \pm 3.00$ & $17.8 \pm 2.75$ \\
\hline Day 15 & $15.2 \pm 3.15$ & $16.0 \pm 2.56$ & $16.6 \pm 3.05^{*}$ \\
\hline Day 20 & $14.6 \pm 3.65$ & $16.3 \pm 2.68^{*}$ & $17.0 \pm 3.15^{* *}$ \\
\hline Day 25 & $13.4 \pm 3.55$ & $16.0 \pm 3.62^{*}$ & $17.7 \pm 2.45^{* * *}$ \\
\hline Day 30 & $12.9 \pm 3.10$ & $16.2 \pm 2.85^{* *}$ & $18.2 \pm 2.59^{* * *}$ \\
\hline
\end{tabular}

Note: statistically significant differences were considered compared with the control group: $* \mathrm{P}<0.05 ; * * \mathrm{P}<0.01 ; * * * \mathrm{P}<0.001$.

During the treatment of animals with the development of toxocariasis with drugs fenbendazole and Ffenbenzyl, it was found that glutathione peroxidase activity on the 15 th day of the experiment increased by 5.3 and $9.2 \%$ compared with the control. On the 20th day of the experiment, glutathione peroxidase activity in blood of dogs of the first experimental group increased by $11.6 \%$, and the second experimental group - by $16.4 \%$ compared with the control. On the 25th day of the experiment, the enzyme activity in dogs of the experimental groups ranged from $16.0 \pm 3.62$ to $17.7 \pm$ $2.45 \mu \mathrm{mol} \mathrm{NADPH} / \mathrm{h} / \mathrm{mg}$ protein, while in the control this figure was $13.4 \pm 3.55 \mu \mathrm{mol}$ $\mathrm{NADPH}_{2} \mathrm{~h} / \mathrm{mg}$ protein. On day 30 of the experiment, glutathione peroxidase activity was the highest in dogs of the second experimental group treated with Ffenbenzyl.

In the study of glutathione reductase activity, it was found that in dogs of the control group, its activity decreased by $21.1 \%$ on the 30 th day of the experiment compared with the initial values (Table 5).

When using the drug fenbendazole in dogs of the first experimental group, on the 15 th day of the experiment, an increase in glutathione reductase activity by $5.5 \%$ was found, on the 20th day of the experiment - by $9.3 \%$, on the 25 th day of the experiment - by $16.1 \%$ and on the 30th day of the experiment - by $12.4 \%$ compared with the control.

When treating dogs of the second experimental group with the drug fFenbenzyl, a more likely increase in glutathione reductase activity was found in comparison with the first experimental group. Thus, on the 10th and 15th day of the experiment, the activity of the enzyme in blood of dogs of the second experimental group increased by 4.0 and $8.8 \%$ in comparison with the control. Subsequently, the glutathione reductase activity continued to increase and, accordingly, on the 20th day of the experiment was $6.24 \pm$ $1.17 \mu \mathrm{mol} \mathrm{NADPH} \mathrm{h} / \mathrm{mg}$ protein, while in the control this figure was $5.47 \pm 1.21 \mu \mathrm{mol}$ $\mathrm{NADPH}_{2} \mathrm{~h} / \mathrm{mg}$ protein. On days 25 and 30 of the experiment, the enzyme activity was the highest in the second experimental group, where it increased by 20.9 and $27.3 \%$, respectively, compared with the control.

Thus, the drug Ffenbenzyl after use in dogs with the development of experimental toxocariasis activated the antioxidant defense system, as indicated by the high content of reduced glutathione and the activity of enzymes of the antioxidant 


\section{The effect of fenbenzyl and fenbendazole on glutathione reductase activity in blood of dogs infected with toxocariasis $(M \pm m, n=6)$}

\begin{tabular}{|l|c|c|c|}
\hline \multirow{2}{*}{ Blood test time (days) } & \multicolumn{3}{|c|}{ Glutathione reductase, $\mu$ mol NADPH, $\mathrm{h} / \mathrm{mg}$ protein } \\
\cline { 2 - 4 } & control & experimental 1 & experimental 2 \\
\cline { 2 - 4 } & $6.37 \pm 1.12$ & $6.38 \pm 1.08$ & $6.40 \pm 1.15$ \\
\hline Before treatment & $6.15 \pm 1.20$ & $6.24 \pm 1.23$ & $6.30 \pm 1.12$ \\
\hline Day 5 & $6.01 \pm 0.85$ & $6.11 \pm 1.10$ & $6.25 \pm 1.00$ \\
\hline Day 10 & $5.82 \pm 0.96$ & $6.14 \pm 1.20$ & $6.33 \pm 1.09$ \\
\hline Day 15 & $5.47 \pm 1.21$ & $5.98 \pm 1.11$ & $6.24 \pm 1.17$ \\
\hline Day 20 & $5.21 \pm 1.30$ & $6.05 \pm 1.22^{*}$ & $6.30 \pm 0.98^{* *}$ \\
\hline Day 30 & $5.02 \pm 0.57$ & $5.64 \pm 0.98^{*}$ & $6.39 \pm 1.10^{* *}$ \\
\hline
\end{tabular}

Note: statistically significant differences were considered compared with the control group: * $\mathrm{P}<0.05 ; * * \mathrm{P}<0.01 ; * * * \mathrm{P}<0.001$.

system: catalase, superoxide dismutase, glutathione peroxidase, and glutathione reductase. This may be due to the fact that the drug contains milk thistle, which has antioxidant properties, as it contains vitamins $\mathrm{B}, \mathrm{A}, \mathrm{E}, \mathrm{K}$, precursors of vitamin $\mathrm{D}$, carotenoids, macronutrients - Calcium, Potassium, Magnesium, Iron and trace elements - Zinc, Copper, Manganese, Iodine.

\section{Conclusions and future perspectives}

The positive effect of the drugs fenbendazole and fFenbenzyl on the indicators of the antioxidant defense system in blood of dogs experimentally infected with the with causative agent of toxocariasis was revealed. It should be noted that the use of the drug fFenbenzyl in infected dogs contributed to a better normalization of the antioxidant system than the use of the drug fenbendazole.

\section{Acknowledgments}

This scientific work was financially supported by the Ministry of Education and Science of Ukraine (0120U101999).

\section{References}

Bodnia, I. P. (2016). Stan adaptyvno-kompensatornykh mozhlyvostei orhanizmu liudyny pry toksokarozi. Hepatolohiia, 4, 19-33.

Grymak, Y., Skoromna, O., Stadnytska, O., Sobolev, O., Gutyj, B., Shalovylo, S., Hachak, Y., Grabovska, O., Bushueva, I., Denys, G., Hudyma, V. Pakholkiv, N.,Jarochovich, I., Nahirniak, T., Pavliv, O., Farionik, T., \& Bratyuk, V. (2020). Influence of "Thireomagnile" and "Thyrioton" preparations on the antioxidant status of pregnant cows. Ukrainian Journal of Ecology, 10(1), 122-126. doi: 10.15421/2020_19

Gutyj, B., Khariv, I., Binkevych, V., Binkevych, O., Levkivska, N., Levkivskyj, D., \& Vavrysevich, Y. (2017). Research on acute and chronic toxity of the experimental drug Amprolinsyl. Regulatory Mechanisms in Biosystems, 8(1), 41-45 doi: 10.15421/021708

Holovakha, V. I., Piddubnyak, O. V., Bakhur, T. I., Vovkotrub, N. V., Antipov, A. A., Anfiorova, M. V., ... \& Macynovich, A. O. (2018). Changes in erythrocytopoesis indices in dogs with babesiosis. Regulatory Mechanisms in Biosystems, 9(3), 379-383. doi:10.15421/021856.

Macuhova, K., Akao, N., Fujinami, Y., Kumagai, T., \& Ohta, N. (2013). Contamination, distribution and pathogenicity of Toxocara canis 
and T. cati eggs from sandpits in Tokyo, Japan. Journal of helminthology, 87, 271-276. doi: 10.1017/S0022149X12000314.

Martyshuk, T. V., Gutyj, B. V., Leskiv, Kh. Ya., Semaniuk, N. V., \& Shnaider, V. L. (2021). The effect of the liposomal drug "butaselmevit" on the enzymatic and non-enzymatic part of the glutatoin system of the blood of rats under oxidative stress. Colloquium-journal, 12(99), 16-19.

Martyshuk, T. V., \& Gutyj, B. V. (2019). Influence of feed additive "Butaselmevit-Plus" on antioxidant status of rats in conditions of oxidative stress. Scientific Messenger of Lviv National University of Veterinary Medicine and Biotechnologies. Series: Agricultural sciences, 21(90), 76-81. doi: 10.32718/nvlvet-a9013.

Martyshuk, T. V., \& Hutyi, B. V. (2021). Imunofiziolohichnyi stan ta antyoksydantnyi potentsial orhanizmu porosiat za umov oksydatsiinoho stresu ta dii koryhuiuchykh chynnykiv: monohrafiia. Lviv: SPOLOM.

Martyshuk, T. V., Gutyj, B. V., \& Vishchur, O. I. (2016). Level of lipid peroxidation products in the blood of rats under the influence of oxidative stress and under the action of liposomal preparation of "Butaselmevit". Biological Bulletin of Bogdan Chmelnitskiy Melitopol State Pedagogical University, 6(2), 22-27. doi: 10.15421/201631.

Moisieieva, N. V., Kapustianska, A. A., Vakhnenko, A. V., Rumiantseva, M. O., \& Kulyk, L. H. (2017). Toksokaroz - suchasni aspekty problemy. Aktualni problemy suchasnoi medytsyny, $17,4(1), 272-277$.

Noor, J., Abbas, A. K., \& Aáiz, N. N. (2019). Serodiagnosis of Toxocariasis by ELISA test using anti- $\mathrm{T}$. canis IgG antibodies in stray dogs compared to PCR. Iraqi Journal of Veterinary Sciences, 33(2), 367-370. doi: 10.33899/ijvs.2019.163081.

Ozlati, M., Spotin, A., Shahbazi, A., Mahami-Oskouei, M., Hazratian, T., Adibpor, M., ... \& Khoshakhlagh, P. (2016). Genetic variability and discrimination of low doses of Toxocara spp. from public areas soil inferred by loop-mediated isothermal amplification assay as a field-friendly molecular tool. Veteri- nary World, 9(12), 1471-1477. doi: 10.14202/ vetworld.2016.1471-1477.

Pryima, O. B. (2010). Osoblyvosti poshyrennia toksokarozu sobak za yikh vikovoiu dynamikoiu. Scientific Messenger of LNU of Veterinary Medicine and Biotechnologies. Series: Veterinary Sciences, 12(2), 254-257.

Robertson, I. D., \& Thomson, R. C. (2002). Enteric parasitic zoonoses of domesticated dogs and cats. Microbes and Infection, 4, 867873. doi: 10.1016/S1286-4579(02)01607-6. Rubinsky-Elefant, G., Hoshino-Shimizu, S., Jacob, C. M. A., Sanchez, M. C. A., \& Ferreira, A. W. (2011). Potential immunological markers for diagnosis and therapeutic assessment of toxocariasis. Revista do Instituto de Medicina Tropical de São Paulo, 53(2), 61-65. doi: 10.1590/S0036-46652011000200001.

Said, W. S., Stybel, V. V., Gytyj, B. V., Pryima, O. B., Sobolta, A. G., Leskiv, K. Y., \& Dytiuk, M. P. (2020). The state of the immune system of dogs in experimental toxocariasis. Ukrainian Journal of Veterinary and Agricultural Sciences, 3(3), 20-24. doi: 10.32718/ujvas3-3.04.

Said, W., Stybel, V. V., Gutyj, B. V., \& Prijma, O. B. (2018). A modern look at the problem of toxocarosis in dogs. Scientific Messenger of LNU of Veterinary Medicine and Biotechnologies. Series: Veterinary Sciences, 20(83), 411-416. doi: 10.15421/nvlvet8380.

Stybel, V., Gutyj, B., \& Said, W. (2021). Effect of fenbenzyl and fenbendazole on peroxide intensity oxidation of lipids in the blood of dogs in experimental toxocariasis. Scientific Messenger of LNU of Veterinary Medicine and Biotechnologies. Series: Veterinary Sciences, 23(101), 107-112. doi: 10.32718/nvlvet10118.

Svirzhevska, Ye. L. (2011). Etiotropna ta patohenetychna terapiia myslyvskykh sobak za larvalnoho toksokarozu. Scientific Messenger of LNU of Veterinary Medicine and Biotechnologies. Series: Veterinary Sciences, 13(4), 375-381.

Toklu, H. Z., Tunali Akbay, T., Velioglu-Ogunc, A., Ercan, F., Gedik, N., Keyer-Uysal, M., et al. (2008). Silymarin, the antioxidant component of silybum marianum, prevents sepsis 
induced acute lung and brain injury. Journal of Surgical Research, 145, 214-222. doi: 10.1016/j.jss.2007.03.072.

Varkholiak, I. S., Gutyj, B. V., Leskiv, Kh. Ya., Kushnir, V. I., Hariv, I. I., Martyshuk, T. V., \& Guta, Z. A. (2021). The effect of bendamine on antioxidant protection of rats' myocardium in doxorubicin intoxication. Colloquium-journal, 7(94), 18-21. doi: 10.24412/2520-6990-2021-794-18-21.

Vidal, J. E., Sztajnbok, J., \& Seguro, A. C. (2003). Eosinophilic meningoencephalitis due to Toxocara canis: case report and review of the literature. The American journal of tropical medicine and hygiene, 69, 341343. doi: 10.4269/ajtmh.2003.69.341.

Vlizlo, V. V., Fedoruk, R. S., \& Ratych, I. B. (2012). Laboratorni metody doslidzhen u biolohiyi, tvarynnytstvi ta veterynarniy medytsyni [Laboratory methods of investigation in biology, stock-breeding and veterinary]. Lviv: SPOLOM.

Zakharchuk, O. I., \& Harazdiuk, H. V. (2014). Problemy toksokarozu liudyny i tvaryn na Bukovyni. Veterynarna medytsyna Ukrainy, 7, 38-39.

Zibaei, M., \& Sadjjadi, S. (2017). Trend of toxocariasis in Iran: A review on human and animal dimensions. Iranian Journal of Veterinary Research, 18(4), 233-242.

В. В. Стибель, Б. В. Гутий, В. С. Саід, К. Куб'як, М. Янковскі, І. А. Максимович, 3. А. Гута, Т. В. Мартишук, В. І. КарповськИй (2021). ВПЛИВ ФЕНБЕНСИЛУ ТА ФЕНБЕНДАЗОЛУ НА АНТИОКСИДАНТНИЙ СТАТУС ОРГАНІЗМУ СОБАК ЗА ЕКСПЕРИМЕНТАЛЬНОГО ІНВАЗУВАННЯ ЗБУДНИКОМ ТОКСОКАРОЗУ. Ukrainian Journal of Veterinary Sciences, 12(2): 5-14, https://doi.org/10.31548/ujvs2021.02.001

Анотація. У статті наведенні результати досліджень впливу фенбенсилу та фенбендазолу на антиоксидантний статус організму собак за експериментального інвазування збудником токсокарозу. Досліди проведено на 18 собаках, дво-чотиримісячного віку. Було сформовано три групи із шести тварин у кожній: контрольну та дві дослідні групи. Цуценят усіх груп експериментально заражали збудником токсокарозу в дозі 5000 інвазійних яєць T. canis на кг маси тіла. Контрольна група собак була в якості нелікованого контролю. Цученятам першої дослідної групи згодовували препарат «Фенбендазол» у дозі 150 мг на 3 кг маси тварини один раз на добу впродовж трьох діб в одноразовій. Цученятам другої дослідної групи згодовували препарат «Фенбенсил» у дозі 350 мг на 3 кг маси тварини один раз на добу впродовж трьох діб. Під час вивчення активності ензимної ланки системи антиоксидантного захисту, а саме каталази, супероксиддисмутази, глутатіонпереоксидази, глутатіонредуктази, а також неензимної ланки: рівня відновленого глутатіону, у тварин дослідних груп встановлено підвищення активності цих показників. Варто зазначити, що застосування препарату «Фенбенсил» інвазованим собакам сприяло кращій нормалізації показників антиоксидантної системи у тварин, ніж застосування препарату «Фенбендазол». Застосування інвазованим собакам препарату «Фенбенсил» сприяло вірогіднішому підвищенню антиоксидантного статусу організму собак другої дослідної групи, оскільки до цього препарату входить розторопша плямиста, яка проявляє антиоксидантні властивості завдяки наявності у своєму складі речовини силімарину, який відновлює пошкоджені клітини печінки. Проведені дослідження підтверджують ефрективність застосування розторопші плямистої в складі препарату «Фенбенсил» собакам за розвитку токсокарозної інвазії для активізації захисних систем їхнього організму.

ключові слова: паразитологія, фармакологія, собаки, антиоксидантна система, розторопша плямиста 